\title{
Kinetics and Mechanism of Chlorate-Chloride Reaction
}

\author{
Rafaela T. P. Sant'Anna, ${ }^{a}$ Cristina M. P. Santos, ${ }^{a}$ Guilherme P. Silva, ${ }^{a}$ Ricardo J. R. Ferreira, ${ }^{a}$ \\ André P. Oliveira, ${ }^{a}$ Carlos E. S. Côrtes ${ }^{b}$ and Roberto B. Faria* ${ }^{*, a}$
}

${ }^{a}$ Instituto de Química, Universidade Federal do Rio de Janeiro, Av. Athos da Silveira Ramos, 149, Centro de Tecnologia, Bloco A, 21941-909 Rio de Janeiro-RJ, Brazil

${ }^{b}$ Instituto de Química, Universidade Federal Fluminense (UFF), Alameda Barros Terra s/n, Morro do Valonguinho, 24210-150 Niterói-RJ, Brazil

\begin{abstract}
O estudo cinético da reação clorato-cloreto foi feito acompanhando-se a formação do $\mathrm{ClO}_{2} \bullet$ por espectroscopia UV-Vis. Para permitir comparação com resultados da literatura, a velocidade inicial foi medida após pequeno período de indução. Observou-se o fenômeno especial de perfil de saturação em função da concentração inicial do cloreto, sugerindo a formação do intermediário $\mathrm{Cl}_{2} \mathrm{O}_{3}{ }^{2-}$. Em baixa concentração de cloreto, as ordens de reação obtidas com relação ao clorato, cloreto e $\mathrm{H}^{+}$foram $1,03 \pm 0,05,1,02 \pm 0,03$ e 2,80 $\pm 0,03$, respectivamente. Estes valores devem ser considerados com cautela pois foram calculados baseados na velocidade máxima após período de indução. Este período de indução indica, na verdade, que o sistema é complexo. Para explicar os resultados experimentais foi proposto um mecanismo contendo a reação entre dois $\mathrm{ClOClO}$ formando $\mathrm{ClO}_{2} \cdot$. Esse mecanismo reproduz as curvas experimentais em diferentes $\left[\mathrm{H}^{+}\right]_{0}$ e também em alto e baixo $\left[\mathrm{Cl}^{-}\right]_{0}$.
\end{abstract}

The kinetics of chlorate-chloride reaction was studied following the formation of $\mathrm{ClO}_{2} \bullet$ by UV-Vis spectroscopy. For comparison with other results in the literature, the initial rate was measured after small induction period. The results show a special effect of a saturation profile for the initial chloride concentration, suggesting the formation of the intermediate $\mathrm{Cl}_{2} \mathrm{O}_{3}{ }^{2-}$. At low chloride concentration, the reaction orders for chlorate, chloride and $\mathrm{H}^{+}$were $1.03 \pm 0.05$, $1.02 \pm 0.03$ and $2.80 \pm 0.03$, respectively. These order values must be considered with care because they were calculated using the maximum rate values after induction period. In fact, the presence of this induction period indicates that the system is complex. Then, a mechanism was proposed to explain the experimental results, and includes the reaction between two $\mathrm{ClOClO}$ to form $\mathrm{ClO}_{2}$. It was able to model the experimental curves at different $\left[\mathrm{H}^{+}\right]_{0}$ and at low and high $\left[\mathrm{Cl}^{-}\right]_{0}$.

Keywords: chlorate, kinetics, mechanism

\section{Introduction}

Despite the fact that chlorine dioxide is aggressive to the environment and subject to many concerns, it is still widely used as an oxidizing species in many important large scale industrial process such as pulp and textile bleaching, and because of its disinfectant properties in water purification and treatment of industrial wastes. Its use as a bleaching agent for wood pulp has the advantage that produces much less chlorinated hydrocarbons than chlorine. ${ }^{1}$

\footnotetext{
*e-mail: faria@iq.ufrj.br
}

Chlorine dioxide is a gas at room temperature and due to its explosive properties it is produced in situ, diluted with inert gases (carbon dioxide or nitrogen, for example) by several reactions. ${ }^{1-3}$ One of the most important preparation method is the reaction between chlorate and chloride in strong acidic condition (generally, $\mathrm{H}_{2} \mathrm{SO}_{4}$ aqueous solution), which has been called $\mathrm{R} 2$ process. ${ }^{4}$

This reaction has been studied by several authors since the beginning of twentieth century, ${ }^{5-9}$ but its mechanism is still a challenge as it occurs simultaneously with related reactions involving chlorite ion, chlorous acid and chlorine dioxide. ${ }^{10,11}$ Indeed, the chlorate chemistry is much less understood than the chlorite and chlorine dioxide chemistry mostly because these species are involved in 
some oscillating reactions. ${ }^{11}$ Only recently, a clock reaction using chlorate was discovered, ${ }^{12,13}$ which in the future may be turned on an oscillating reaction.

From the point of view of the stoichiometry, it is well accepted that $\mathrm{Cl}_{2}$ is formed together with $\mathrm{ClO}_{2} \bullet$ in a proportion of 1:2 following the global reaction in aqueous solution equation 1 .

$2 \mathrm{ClO}_{3}^{-}+2 \mathrm{Cl}^{-}+4 \mathrm{H}^{+} \rightarrow \mathrm{Cl}_{2}+2 \mathrm{ClO}_{2} \bullet+2 \mathrm{H}_{2} \mathrm{O}$

The 1:2 proportion can be explained considering the initial formation of $\mathrm{HClO}_{2}$ and $\mathrm{HOCl}$, and the reaction of these species with additional chlorate and chloride, respectively, as indicated by equations $2-4:{ }^{4}$

$$
\begin{aligned}
& \mathrm{ClO}_{3}^{-}+\mathrm{Cl}^{-}+2 \mathrm{H}^{+} \rightarrow \mathrm{HClO}_{2}+\mathrm{HOCl} \\
& \mathrm{HClO}_{2}+\mathrm{ClO}_{3}^{-}+\mathrm{H}^{+} \rightarrow 2 \mathrm{ClO}_{2} \cdot+\mathrm{H}_{2} \mathrm{O} \\
& \mathrm{HOCl}+\mathrm{Cl}^{-}+\mathrm{H}^{+} \rightarrow \mathrm{Cl}_{2}+\mathrm{H}_{2} \mathrm{O}
\end{aligned}
$$

However, this stoichiometry is obeyed only at low chloride ion concentrations because at high chloride concentration more chlorine is formed. ${ }^{4,14}$ In fact, several kinetic studies has shown that this reaction is much more complex than equations 1-4 may suggest. The rate law given by equation 5 has been observed by several authors in sulfuric or perchloric acid aqueous solutions, but the orders may depend on concentrations: $\mathrm{a}=1$ at high acid concentration but increases until approximately 2 at low acid concentration, $b$ is close to 2 in several studies, and $11<\mathrm{c}<13$, with the lower values at low acid concentration. ${ }^{14-16}$

$$
\mathrm{d}\left[\mathrm{ClO}_{2} \cdot{ }^{\bullet}\right] / \mathrm{dt}=\left[\mathrm{ClO}_{3}^{-}\right]^{\mathrm{a}}\left[\mathrm{Cl}^{-}\right]^{\mathrm{b}}\left[\mathrm{H}^{+}\right]^{\mathrm{c}}
$$

The exceptionally high order for $\mathrm{H}^{+}$has been interpreted by some authors as an effect of the high activity of water in concentrated sulfuric or perchloric acid solutions. ${ }^{15,16}$ The Hammett acidity function $h-$ has also been used to reduce the $\mathrm{H}^{+}$order to $2.4 .{ }^{17}$ Moreover, when the reaction was studied in $\mathrm{HCl}$ solution,, 89 the observed order of $\mathrm{H}^{+}$was in the range of 2 to 4 .

Both facts, the very high $\mathrm{H}^{+}$order in sulfuric acid solution and a lower order in $\mathrm{HCl}$ solution were our initial motivation to reinvestigate this reaction. In addition, all results in literature described above were obtained without keeping the ionic strength constant which is another strong reason to reinvestigate that reaction.

The experimental results obtained in this work and the proposed mechanism are a contribution to the understanding of the aqueous oxohalogen chemistry, which still presents many uncertainties concerning the intermediates involved (see, for example, the chlorous acid/ chlorite ion reactions). ${ }^{11,18,19}$ Differently from these works, the present article deals with chlorate chemistry which has few works including modeling by numerical integration of the proposed mechanism. ${ }^{12,13}$

\section{Experimental}

Chlorate-chloride reaction was followed using UV-Vis spectroscopy. Full spectra were obtained using the HP-8452A diode-array spectrophotometer. Kinetics was done using a Hi-Tech Dual Mixing Microvolume Stopped-Flow SF-61DX2 at $25.0 \pm 0.1^{\circ} \mathrm{C}$.

Analytical grade chemicals $\mathrm{NaClO}_{3}, \mathrm{HClO}_{4}, \mathrm{NaCl}$, $\mathrm{NaClO}_{4}$ (Merck), $\mathrm{HCl}$ and $\mathrm{H}_{2} \mathrm{SO}_{4}$ (Vetec) were used without further purification. Water was obtained by a Milli-Q Plus purification system.

When following the reaction by formation of $\mathrm{ClO}_{2} \bullet$ at $358 \mathrm{~nm}\left(\varepsilon=1250 \mathrm{~mol}^{-1} \mathrm{~L} \mathrm{~cm}^{-1}\right)^{20}$ or $400 \mathrm{~nm}$ $\left(\varepsilon=607 \mathrm{~mol}^{-1} \mathrm{~L} \mathrm{~cm}^{-1}\right)$, the initial rate $\left(v_{0}=\mathrm{d}\left[\mathrm{ClO}_{2} \cdot\right] / \mathrm{dt}\right)$ was determined after a small induction period (which ranges from 2 to $5 \mathrm{~s}$, depending on the reactant concentrations) by fitting a second degree polynomial to the curve of $\mathrm{ClO}_{2}$. concentration $v s$. time, as already done by our group in a similar study. ${ }^{21}$ However, these ones cannot be considered strict initial rate values, because there is an induction period before the maximum rate attainment. In addition, when following the reaction at $358 \mathrm{~nm}$, the absorbance value contains some contribution from $\mathrm{Cl}_{2}$ and $\mathrm{Cl}_{3}^{-}$, which also absorb at this wavelength. These results obtained at both wavelengths are of great value when checking the proposed mechanism by numerical integration because they demonstrate the model ability to reproduce data obtained at different conditions.

Numerical integration was done using a program written by Dr. István Lengyel, in Turbo Pascal (now Free Pascal, version 1.0.8, compiler version 2.0.4) to solve autonomous ordinary differential equation systems by a semi-implicit Runge-Kutta method. ${ }^{22}$

\section{Results}

Figure 1 shows the spectra taken at every 2 min for the chlorate-chloride reaction in both conditions, excess of chlorate (Figure 1a) and excess of chloride (Figure 1b), in the range of 250 to $450 \mathrm{~nm}$. Figure 2 shows the spectra of the main species that absorb at this wavelength range. As can be seen by comparison of these figures, the formation of $\mathrm{ClO}_{2} \cdot$ occurs in both cases, independently of the chloride:chlorate ratio. In addition, it was not observed an increase in chlorine formation at high chloride:chlorate 
ratio, as indicated by some authors. ${ }^{14,23,24}$ This does not mean that chlorine has not been formed. Spectral simulation (not shown) for a solution containing a $1: 2$ ratio for $\mathrm{Cl}_{2}: \mathrm{ClO}_{2}$ • gives the same band profile of a $\mathrm{ClO}_{2} \bullet$ solution because the molar absorptivity of the second is much higher than
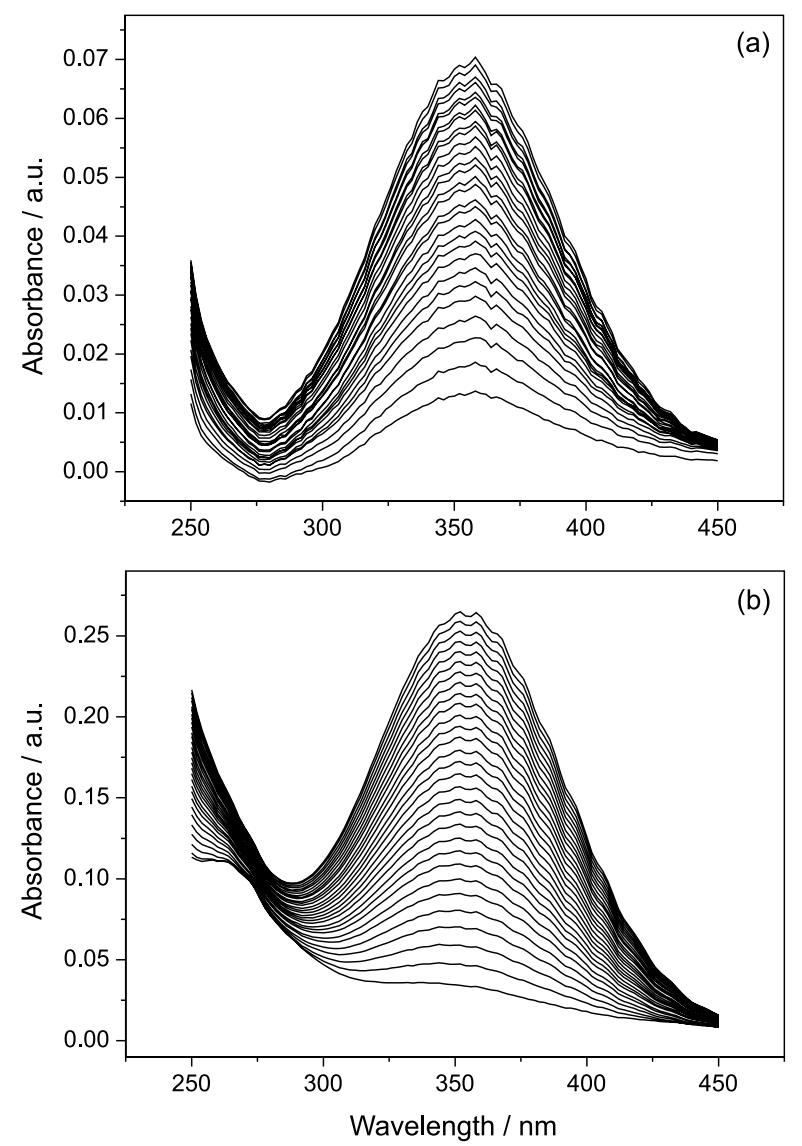

Figure 1. Evolution of the chorate-chloride reaction: (a) excess of chlorate: $\left[\mathrm{NaClO}_{3}\right]_{0}=1.25 \mathrm{~mol} \mathrm{~L}^{-1},[\mathrm{NaCl}]_{0}=0.0250 \mathrm{~mol} \mathrm{~L}^{-1}$ and $\left[\mathrm{HClO}_{4}\right]_{0}=2.00 \mathrm{~mol} \mathrm{~L} \mathrm{~L}^{-1}$, and (b) excess of chloride: $\left[\mathrm{NaClO}_{3}\right]_{0}=0.0500 \mathrm{~mol} \mathrm{~L}-1,[\mathrm{NaCl}]_{0}=0.500 \mathrm{~mol} \mathrm{~L}^{-1}$ and $\left[\mathrm{HClO}_{4}\right]_{0}=2.00 \mathrm{~mol} \mathrm{~L}^{-1}$. Spectra were taken at every $2 \mathrm{~min}$.

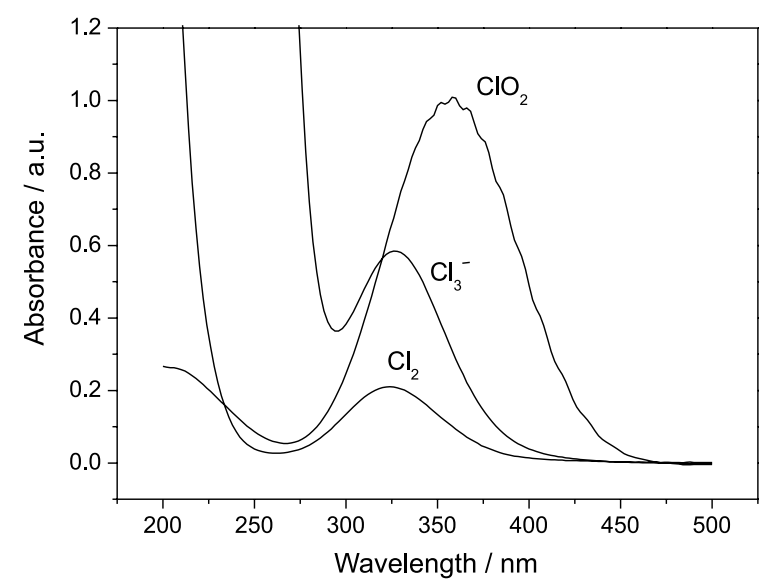

Figure 2. UV-Vis spectra of some chlorine containing inorganic species in aqueous solution. Spectra were multiplied by different arbitrary factors to facilitate comparison of $\lambda_{\max }$.

of chlorine $\left(\varepsilon\left(\mathrm{ClO}_{2} \cdot \lambda_{\max }\right.\right.$ at $\left.358 \mathrm{~nm}\right)=1250 \mathrm{~mol}^{-1} \mathrm{~L} \mathrm{~cm}^{-1}$; $\varepsilon\left(\mathrm{Cl}_{2}, \lambda_{\text {max }}\right.$ at $\left.\left.325 \mathrm{~nm}\right)=70 \mathrm{~mol}^{-1} \mathrm{~L} \mathrm{~cm}^{-1}\right)$ and $\lambda_{\text {max }}$ for both species are very close. ${ }^{20,25}$ Even considering the equilibrium of chlorine with $\mathrm{Cl}_{3}{ }^{-}\left(K=0.18,25^{\circ} \mathrm{C}\right)$, the simulated spectra do not change because of the same reasons $\left(\varepsilon\left(\mathrm{Cl}_{3}^{-}, \lambda_{\max }\right.\right.$ at $\left.325 \mathrm{~nm})=180 \mathrm{~mol}^{-1} \mathrm{~L} \mathrm{~cm}^{-1}\right){ }^{20}$

As it was decided to investigate this reaction using $\mathrm{HCl}$ as a simultaneous source of $\mathrm{H}^{+}$and chloride, our first experiments to measure the reaction order of reactants were done at high chloride concentration because the reaction is very slow when $\left[\mathrm{H}^{+}\right]_{0}$ is lower than $3.0 \mathrm{~mol} \mathrm{~L}-1$ (many of our experiments were done at $\left.\left[\mathrm{H}^{+}\right]_{0}=3.8 \mathrm{~mol} \mathrm{~L}^{-1}\right)$, a consequence of the low equilibrium constant for reaction 1 $\left(K=4.7 \times 10^{-7}\right) .{ }^{23}$ During this investigation, when obtaining the order for chloride, a very intriguing result was observed as $\mathrm{HCl}$ was substituted for $\mathrm{HClO}_{4}$ to decrease the initial chloride concentration, maintaining $\left[\mathrm{H}^{+}\right]_{0}$ constant, the initial rate values were very similar, as can be seen in Table 1 and Figure 3.

Table 1. Effect of the initial chloride concentration $\left(\left[\mathrm{Cl}^{-}\right]_{0}=[\mathrm{HCl}]_{0}\right)$ on the initial rate $\left(v_{0}=\mathrm{d}\left[\mathrm{ClO}_{2} \bullet / \mathrm{dt}\right.\right.$, following the reaction at $\left.358 \mathrm{~nm}\right)$ for the chlorate-chloride reaction by substitution of perchloric acid for hydrochloric acid, at constant values for $\left[\mathrm{H}^{+}\right]_{0}\left(3.8 \mathrm{~mol} \mathrm{~L}^{-1}\right)$, $\left[\mathrm{NaClO}_{3}\right]_{0}$ and $I$. Initial concentrations are in $\mathrm{mol} \mathrm{L}^{-1}$

\begin{tabular}{|c|c|c|c|c|c|}
\hline$[\mathrm{HCl}]_{0}$ & {$\left[\mathrm{HClO}_{4}\right]_{0}$} & {$\left[\mathrm{ClO}_{4}^{-}\right]_{0} /\left[\mathrm{Cl}^{-}\right]_{0}$} & $\begin{array}{c}v_{0} /\left(10^{-5} \mathrm{~mol} \mathrm{~L}^{-1} \mathrm{~s}^{-1}\right) \text { at } \\
{\left[\mathrm{NaClO}_{3}\right]=0.10 \mathrm{~mol} \mathrm{~L}^{-1}} \\
I=3.9 \mathrm{~mol} \mathrm{~L}^{-1}\end{array}$ & $\begin{array}{c}v_{0} /\left(10^{-5} \mathrm{~mol} \mathrm{~L}^{-1} \mathrm{~s}^{-1}\right) \text { at } \\
{\left[\mathrm{NaClO}_{3}\right]=0.20 \mathrm{~mol} \mathrm{~L}^{-1}} \\
I=4.0 \mathrm{~mol} \mathrm{~L}^{-1}\end{array}$ & $\begin{array}{c}v_{0} /\left(10^{-4} \mathrm{~mol} \mathrm{~L}^{-1} \mathrm{~s}^{-1}\right) \text { at } \\
{\left[\mathrm{NaClO}_{3}\right]=0.40 \mathrm{~mol} \mathrm{~L}^{-1}} \\
I=4.2 \mathrm{~mol} \mathrm{~L}^{-1}\end{array}$ \\
\hline 3.8 & 0.0 & 0.0 & $2.84 \pm 0.098$ & $6.96 \pm 0.29$ & $1.81 \pm 0.08$ \\
\hline 3.3 & 0.5 & 0.152 & $2.60 \pm 0.07$ & $7.24 \pm 0.24$ & $1.74 \pm 0.06$ \\
\hline 2.8 & 1.0 & 0.357 & $2.47 \pm 0.07$ & $6.54 \pm 0.56$ & $1.63 \pm 0.05$ \\
\hline 2.3 & 1.5 & 0.652 & $2.34 \pm 0.096$ & $6.56 \pm 0.18$ & $1.51 \pm 0.06$ \\
\hline 1.8 & 2.0 & 1.111 & $2.43 \pm 0.08$ & $6.52 \pm 0.51$ & $1.42 \pm 0.05$ \\
\hline 1.6 & 2.2 & 1.375 & $2.39 \pm 0.27$ & $5.55 \pm 0.40$ & - \\
\hline 1.4 & 2.4 & 1.714 & $2.28 \pm 0.17$ & $4.78 \pm 0.24$ & - \\
\hline 1.3 & 2.5 & 1.923 & $1.84 \pm 0.12$ & $4.37 \pm 0.33$ & $1.14 \pm 0.03$ \\
\hline 0.8 & 3.0 & 3.750 & $0.924 \pm 0.073$ & $2.95 \pm 0.28$ & $0.929 \pm 0.070$ \\
\hline 0.3 & 3.5 & 11.67 & - & - & $0.0176 \pm 0.0007$ \\
\hline
\end{tabular}




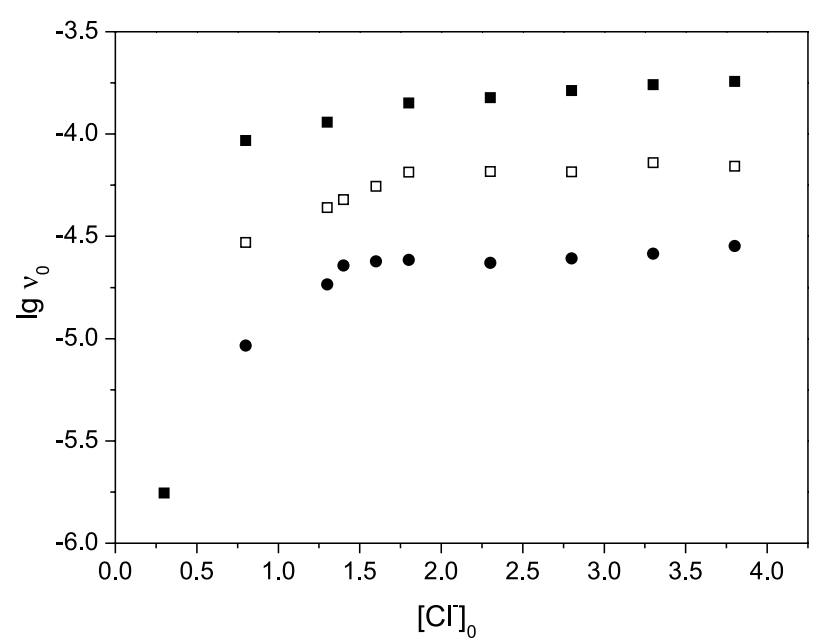

Figure 3. Plot in logarithm scale of initial rate values at different $\left[\mathrm{Cl}^{-}\right]_{0}$ and at three different $\left[\mathrm{ClO}_{3}^{-}\right]_{0}:(\square) 0.4,(\square) 0.2$ and $(\bullet) 0.1 \mathrm{~mol} \mathrm{~L}^{-1}$ (see Table 1).

Data in Table 1 allow to determine the chloride order by a $\log$ (initial rate) $\times \log \left[\mathrm{Cl}^{-}\right]_{0}$ plot. Considering only the values for $\left[\mathrm{Cl}^{-}\right]_{0}>1.5 \mathrm{~mol} \mathrm{~L}^{-1}$, it was obtained 0.17 , 0.22 and 0.27 for the chloride order at $\left[\mathrm{NaClO}_{3}\right]_{0}=0.10$, 0.20 and $0.40 \mathrm{~mol} \mathrm{~L}^{-1}$, respectively. These results indicate that chloride order is essentially zero at high $\left[\mathrm{Cl}^{-}\right]_{0}$.

Initially, it has been supposed that perchlorate was reacting because the decrease of $[\mathrm{HCl}]_{0}$ is compensated with an increase of $\left[\mathrm{HClO}_{4}\right]_{0}$ in order to keep the total concentration of acid constant. To check this possibility, it was decided to use sulfuric acid in place of perchloric acid. As the $\mathrm{p} K_{\mathrm{a}}$ for the ionization of the second $\mathrm{H}^{+}$of the sulfuric acid is $1.98,{ }^{26}$ this acid can be considered as monoprotic in our conditions. The results are shown in Table 2.

Again, the initial rate values are almost the same for a huge change in $\left[\mathrm{Cl}^{-}\right]_{0}$ from 3.8 to $1.0 \mathrm{~mol} \mathrm{~L}^{-1}$ and it was supposed that bisulfate ion was also reacting. But when paying attention on the lowest chloride concentration in Table 1, the initial rate values start to be sensible to $\left[\mathrm{Cl}^{-}\right]_{0}$. Then, it was decided to measure the rate of reaction at low $\left[\mathrm{Cl}^{-}\right]_{0}$. The results are shown in Table 3.

Now, it can be seen that the initial rate decreases accompanied by the $\left[\mathrm{Cl}^{-}\right]_{0}$ decrease. The linear regression of the $\log$ (initial rate) $\times \log \left[\mathrm{Cl}^{-}\right]_{0}$ plot gives an order equal to $1.02 \pm 0.03\left(\mathrm{R}^{2}=0.996\right)$, indicating a first-order behavior for chloride. The $\log$ (initial rate) $\times \log \left[\mathrm{Cl}^{-}\right]_{0}$ plot for all data in Tables 2 and 3 is shown in Figure 4, together with the linear fit for the low chloride concentration.

The results in Tables 1,2 and 3 and Figures 3 and 4 show that at high chloride concentration, the initial rate becomes independent of the chloride concentration. This saturation profile for chloride suggests the formation of an intermediate between chlorate and chloride by a fast equilibrium.
Table 2. Effect of the initial chloride concentration $\left(\left[\mathrm{Cl}^{-}\right]_{0}=[\mathrm{HCl}]_{0}\right)$ on the initial rate $\left(v_{0}=\mathrm{d}\left[\mathrm{ClO}_{2} \cdot\right] / \mathrm{dt}\right.$, following the reaction at $\left.400 \mathrm{~nm}\right)$ for the chlorate-chloride reaction by substitution of sulfuric acid for hydrochloric acid, at constant values for $\left[\mathrm{H}^{+}\right]_{0}\left(3.8 \mathrm{~mol} \mathrm{~L}^{-1}\right),\left[\mathrm{NaClO}_{3}\right]_{0}$ $\left(0.21 \mathrm{~mol} \mathrm{~L}^{-1}\right)$ and $I\left(4.01 \mathrm{~mol} \mathrm{~L}^{-1}\right)$. Initial concentrations are in $\mathrm{mol} \mathrm{L}^{-1}$

\begin{tabular}{lcc}
\hline$[\mathrm{HCl}]_{0}$ & {$\left[\mathrm{H}_{2} \mathrm{SO}_{4}\right]_{0}$} & $\mathrm{v}_{0} /\left(10^{-5} \mathrm{~mol} \mathrm{~L}^{-1} \mathrm{~s}^{-1}\right)$ \\
\hline 3.8 & 0.0 & $5.71 \pm 0.16$ \\
3.6 & 0.2 & $6.05 \pm 0.21$ \\
3.4 & 0.4 & $5.97 \pm 0.14$ \\
3.2 & 0.6 & $6.22 \pm 0.18$ \\
3.0 & 0.8 & $5.84 \pm 0.36$ \\
2.8 & 1.0 & $6.95 \pm 0.28$ \\
2.6 & 1.2 & $6.94 \pm 0.26$ \\
2.4 & 1.4 & $6.78 \pm 0.29$ \\
2.2 & 1.6 & $7.37 \pm 0.18$ \\
2.0 & 1.8 & $7.54 \pm 0.24$ \\
1.8 & 2.0 & $7.95 \pm 0.36$ \\
1.6 & 2.2 & $6.97 \pm 0.39$ \\
1.4 & 2.4 & $6.98 \pm 0.29$ \\
1.2 & 2.6 & $6.59 \pm 0.30$ \\
1.0 & 2.8 & $6.57 \pm 0.09$ \\
\hline
\end{tabular}

Table 3. Effect of the initial chloride concentration $\left(\left[\mathrm{Cl}^{-}\right]_{0}=[\mathrm{HCl}]_{0}\right)$ on the initial rate $\left(v_{0}=\mathrm{d}\left[\mathrm{ClO}_{2} \cdot\right] / \mathrm{dt}\right.$, following the reaction at $\left.400 \mathrm{~nm}\right)$ for the chlorate-chloride reaction, using low chloride concentration, by substitution of sulfuric acid for hydrochloric acid, at constant values for $\left[\mathrm{H}^{+}\right]_{0}\left(3.8 \mathrm{~mol} \mathrm{~L}^{-1}\right),\left[\mathrm{NaClO}_{3}\right]_{0}\left(0.2 \mathrm{~mol} \mathrm{~L}^{-1}\right)$ and $I\left(4.0 \mathrm{~mol} \mathrm{~L}^{-1}\right)$. Initial concentrations are in $\mathrm{mol} \mathrm{L}^{-1}$

\begin{tabular}{lcc}
\hline$[\mathrm{HCl}]_{0}$ & {$\left[\mathrm{H}_{2} \mathrm{SO}_{4}\right]_{0}$} & $\mathrm{v}_{0} /\left(10^{-5} \mathrm{~mol} \mathrm{~L}^{-1} \mathrm{~s}^{-1}\right)$ \\
\hline 0.8 & 3.0 & $5.47 \pm 0.19$ \\
0.7 & 3.1 & $4.87 \pm 0.38$ \\
0.6 & 3.2 & $4.26 \pm 0.28$ \\
0.5 & 3.3 & $3.82 \pm 0.33$ \\
0.4 & 3.4 & $2.85 \pm 0.12$ \\
0.2 & 3.6 & $1.47 \pm 0.099$ \\
0.1 & 3.7 & $0.651 \pm 0.051$ \\
\hline
\end{tabular}

For the order respective to the chlorate, Tables 4, 5 and 6 present the initial rate results obtained at $\left[\mathrm{Cl}^{-}\right]_{0}$ equal to $0.4,2.5$ and $3.8 \mathrm{~mol} \mathrm{~L}^{-1}$. The linear regressions of the $\log$ (initial rate) $\times \log \left[\mathrm{ClO}_{3}^{-}\right]_{0}$ plot show order values equal to $1.03 \pm 0.05\left(\mathrm{R}^{2}=0.993\right), 1.21 \pm 0.02\left(\mathrm{R}^{2}=0.9988\right)$ and $1.33 \pm 0.03\left(\mathrm{R}^{2}=0.9982\right)$, respectively, indicating a first-order behavior for chlorate at low chloride initial concentration and a small increase of this order with the $\left[\mathrm{Cl}^{-}\right]_{0}$ increase.

Data presented in Table 7 allow to calculate an order respective to $\mathrm{H}^{+}$equal to $2.80 \pm 0.03\left(\mathrm{R}^{2}=0.9995\right)$ at low chloride concentration $\left(\left[\mathrm{Cl}^{-}\right]_{0}=0.5 \mathrm{~mol} \mathrm{~L}^{-1}\right)$. At high chloride concentration $\left(\left[\mathrm{Cl}^{-}\right]_{0}=3.8 \mathrm{~mol} \mathrm{~L}-1\right)$, this order increases to $4.23 \pm 0.10\left(\mathrm{R}^{2}=0.9984\right)$ (Table 8). 


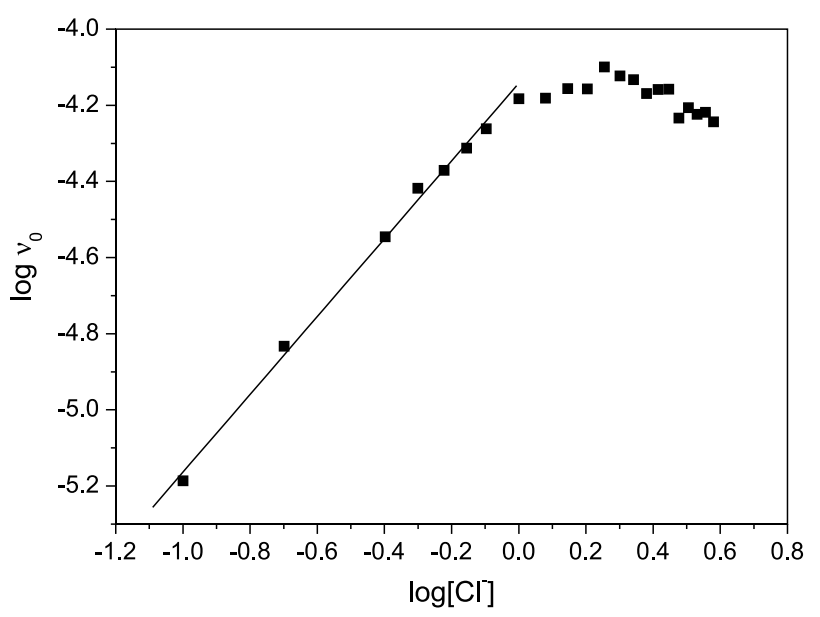

Figure 4. Plot in logarithm scale of initial rate values at different $\left[\mathrm{Cl}^{-}\right]_{0}$ for the data in Tables 2 and 3. The solid line is the linear fit for the data in Table 3.

Table 4. Effect of the initial chlorate concentration on the initial rate $\left(v_{0}=\mathrm{d}\left[\mathrm{ClO}_{2} \cdot\right] / \mathrm{dt}\right.$, following the reaction at $\left.400 \mathrm{~nm}\right)$ for the chlorate-chloride reaction at low chloride initial concentration, $\left[\mathrm{Cl}^{-}\right]_{0}=0.4 \mathrm{~mol} \mathrm{~L}^{-1}$, $\left[\mathrm{H}^{+}\right]_{0}=3.8 \mathrm{~mol} \mathrm{~L}^{-1},[\mathrm{HCl}]=0.4 \mathrm{~mol} \mathrm{~L}^{-1},\left[\mathrm{H}_{2} \mathrm{SO}_{4}\right]_{0}=3.4 \mathrm{~mol} \mathrm{~L}^{-1}$ and $I=4.3 \mathrm{~mol} \mathrm{~L}^{-1}$. Initial concentrations are in $\mathrm{mol} \mathrm{L}^{-1}$

\begin{tabular}{lcc}
\hline$\left[\mathrm{NaClO}_{3}\right]_{0}$ & {$\left[\mathrm{NaClO}_{4}\right]_{0}$} & $\mathrm{v}_{0} /\left(10^{-5} \mathrm{~mol} \mathrm{~L}^{-1} \mathrm{~s}^{-1}\right)$ \\
\hline 0.1 & 0.4 & $2.14 \pm 0.23$ \\
0.2 & 0.3 & $4.76 \pm 0.41$ \\
0.3 & 0.2 & $6.68 \pm 0.59$ \\
0.4 & 0.1 & $8.52 \pm 0.73$ \\
0.5 & 0.0 & $10.2 \pm 1.7$ \\
\hline
\end{tabular}

Table 5. Effect of the initial chlorate concentration on the initial rate $\left(v_{0}=\mathrm{d}\left[\mathrm{ClO}_{2} \cdot\right] / \mathrm{dt}\right.$, following the reaction at $\left.400 \mathrm{~nm}\right)$ for the chlorate-chloride reaction at intermediate chloride initial concentration, $\left[\mathrm{Cl}^{-}\right]_{0}=2.5 \mathrm{~mol} \mathrm{~L}^{-1}$, $\left[\mathrm{H}^{+}\right]_{0}=3.8 \mathrm{~mol} \mathrm{~L}^{-1},[\mathrm{HCl}]_{0}=2.5 \mathrm{~mol} \mathrm{~L}^{-1},\left[\mathrm{H}_{2} \mathrm{SO}_{4}\right]_{0}=1.3 \mathrm{~mol} \mathrm{~L}^{-1}$ and $I=4.3 \mathrm{~mol} \mathrm{~L}^{-1}$. Initial concentrations are in $\mathrm{mol} \mathrm{L}^{-1}$

\begin{tabular}{lcc}
\hline$\left[\mathrm{NaClO}_{3}\right]_{0}$ & {$\left[\mathrm{NaClO}_{4}\right]_{0}$} & $v_{0} /\left(10^{-5} \mathrm{~mol} \mathrm{~L}^{-1} \mathrm{~s}^{-1}\right)$ \\
\hline 0.1 & 0.4 & $4.01 \pm 0.28$ \\
0.2 & 0.3 & $9.53 \pm 0.38$ \\
0.3 & 0.2 & $16.0 \pm 0.50$ \\
0.4 & 0.1 & $22.0 \pm 0.88$ \\
0.5 & 0.0 & $27.6 \pm 0.75$ \\
\hline
\end{tabular}

Based on the set of the results presented above and using the $\mathrm{H}^{+}$order equal to 2.80 as an indication for a third-order behavior for this species, it is achieved the rate law shown in equation 6 for low chloride concentration. The $k$ value was calculated based only in the data from Table 7 and is for low chloride concentration and ionic strength $4.0 \mathrm{~mol} \mathrm{~L}^{-1}$.

$\mathrm{v}=\mathrm{d}\left[\mathrm{ClO}_{2} \cdot\right] / \mathrm{dt}=k\left[\mathrm{ClO}_{3}^{-}\right]\left[\mathrm{Cl}^{-}\right]\left[\mathrm{H}^{+}\right]^{3}$

$k=(3.86 \pm 0.04) \times 10^{-6} \mathrm{~mol}^{-4} \mathrm{~L}^{4} \mathrm{~s}^{-1}$
Table 6. Effect of the initial chlorate concentration on the initial rate $\left(v_{0}=\mathrm{d}\left[\mathrm{ClO}_{2} \cdot\right] / \mathrm{dt}\right.$, following the reaction at $\left.400 \mathrm{~nm}\right)$ for the chlorate-chloride reaction at high chloride initial concentration, $\left[\mathrm{Cl}^{-}\right]_{0}=3.8 \mathrm{~mol} \mathrm{~L}^{-1},\left[\mathrm{H}^{+}\right]_{0}=3.8 \mathrm{~mol} \mathrm{~L}^{-1},[\mathrm{HCl}]_{0}=3.8 \mathrm{~mol} \mathrm{~L}^{-1}$ and $I=4.3 \mathrm{~mol} \mathrm{~L}^{-1}$. Initial concentrations are in $\mathrm{mol} \mathrm{L}^{-1}$

\begin{tabular}{lcc}
\hline$\left[\mathrm{NaClO}_{3}\right]_{0}$ & {$\left[\mathrm{NaClO}_{4}\right]_{0}$} & $\mathrm{v}_{0} /\left(10^{-5} \mathrm{~mol} \mathrm{~L}^{-1} \mathrm{~s}^{-1}\right)$ \\
\hline 0.05 & 0.45 & $1.33 \pm 0.05$ \\
0.10 & 0.40 & $3.53 \pm 0.05$ \\
0.15 & 0.35 & $6.26 \pm 0.14$ \\
0.20 & 0.30 & $8.79 \pm 0.24$ \\
0.25 & 0.25 & $11.4 \pm 0.2$ \\
0.30 & 0.20 & $14.3 \pm 0.2$ \\
\hline
\end{tabular}

Table 7. Effect of the initial $\mathrm{H}^{+}$concentration on the initial rate $\left(v_{0}=\mathrm{d}\left[\mathrm{ClO}_{2} \cdot\right] / \mathrm{dt}\right.$, following the reaction at $\left.400 \mathrm{~nm}\right)$ for the chlorate-chloride reaction at low chloride initial concentration, $\left[\mathrm{Cl}^{-}\right]_{0}=0.5 \mathrm{~mol} \mathrm{~L}^{-1}$, $\left[\mathrm{NaClO}_{3}\right]_{0}=0.2 \mathrm{~mol} \mathrm{~L}^{-1},\left[\mathrm{HClO}_{4}\right]_{0}=3.3 \mathrm{~mol} \mathrm{~L}^{-1}$ and $I=4.0 \mathrm{~mol} \mathrm{~L}-1$. Initial concentrations are in $\mathrm{mol} \mathrm{L}^{-1}$

\begin{tabular}{lccc}
\hline$[\mathrm{NaCl}]_{0}$ & {$[\mathrm{HCl}]_{0}$} & {$\left[\mathrm{H}^{+}\right]_{0}$} & $\mathrm{v}_{0} /\left(10^{-5} \mathrm{~mol} \mathrm{~L}^{-1} \mathrm{~s}^{-1}\right)$ \\
\hline 0.0 & 0.5 & 3.8 & $2.08 \pm 0.08$ \\
0.2 & 0.3 & 3.6 & $1.80 \pm 0.07$ \\
0.3 & 0.2 & 3.5 & $1.66 \pm 0.04$ \\
0.4 & 0.1 & 3.4 & $1.53 \pm 0.06$ \\
0.5 & 0.0 & 3.3 & $1.40 \pm 0.06$ \\
\hline
\end{tabular}

Table 8. Effect of the initial $\mathrm{H}^{+}$concentration on the initial rate $\left(v_{0}=\mathrm{d}\left[\mathrm{ClO}_{2} \cdot\right] / \mathrm{dt}\right.$, following the reaction at $\left.400 \mathrm{~nm}\right)$ for the chlorate-chloride reaction at high chloride initial concentration, $\left[\mathrm{Cl}^{-}\right]_{0}=3.8 \mathrm{~mol} \mathrm{~L}^{-1}$, $\left[\mathrm{NaClO}_{3}\right]_{0}=0.2 \mathrm{~mol} \mathrm{~L}^{-1}$ and $I=4.0 \mathrm{~mol} \mathrm{~L}^{-1}$. Initial concentrations are in $\mathrm{mol} \mathrm{L}^{-1}$

\begin{tabular}{lccc}
\hline$[\mathrm{NaCl}]_{0}$ & {$[\mathrm{HCl}]_{0}$} & {$\left[\mathrm{H}^{+}\right]_{0}$} & $\mathrm{v}_{0} /\left(10^{-5} \mathrm{~mol} \mathrm{~L}^{-1} \mathrm{~s}^{-1}\right)$ \\
\hline 0.0 & 3.8 & 3.8 & $7.21 \pm 0.25$ \\
0.2 & 3.6 & 3.6 & $5.77 \pm 0.29$ \\
0.4 & 3.4 & 3.4 & $4.67 \pm 0.11$ \\
0.6 & 3.2 & 3.2 & $3.47 \pm 0.07$ \\
0.8 & 3.0 & 3.0 & $2.67 \pm 0.10$ \\
\hline
\end{tabular}

It is worth to say that this rate law was obtained using initial rate values measured after an initial induction period. The presence of this induction period does not allow to obtain a rate law and only the kinetic modeling can be used to describe the course of reaction. In doing this, the order determined for each species can be considered as a guide to build a mechanistic model. However, this rate law can be compared with the rate laws obtained by other authors using similar procedures, as they did not notice the existence of an induction period.

\section{Discussion}

Despite the fact that the rate law given by equation 6 for low chloride concentration must be considered with 
care, it is interesting to compare it with other results in literature. ${ }^{10,14-16}$ When doing this, it presents some significant differences. The first-order for chlorate is in agreement with other studies, some of them indicating that its value increases at low acidity. It was not measured at low acidity as our results were obtained only in the range $3.0 \mathrm{~mol} \mathrm{~L}-1 \leq\left[\mathrm{H}^{+}\right]_{0} \leq 3.8 \mathrm{~mol} \mathrm{~L}^{-1}$. The increase of this order from 1.0 to 1.33 as $\left[\mathrm{Cl}^{-}\right]_{0}$ is increased from 0.5 to $3.8 \mathrm{~mol} \mathrm{~L}^{-1}$ has not been reported before.

The first-order for chloride does not agree with other reported results that had established a second-order behavior for this ion. ${ }^{10,14-16}$ The reason for this disagreement can be attributed to fact that all results in the literature were obtained without keeping the ionic strength constant. Thus all results reported for this reaction until now may carry some error. In addition to this first-order behavior at low chloride concentration, it was observed that this reaction order approaches zero as the chloride concentration was increased above $1 \mathrm{~mol} \mathrm{~L}^{-1}$, producing an initial rate saturation profile for this ion, as can be seen in Figure 3 and Tables 1 and 2 . This suggests a fast equilibrium between chlorate and chloride that may form, for example, $\mathrm{Cl}_{2} \mathrm{O}_{3}{ }^{2-}$ species, as shown in equation 7. At high $\left[\mathrm{Cl}^{-}\right]$, this equilibrium is shift to the right side in such way that additional $\left[\mathrm{Cl}^{-}\right]_{0}$ does not increases $\left[\mathrm{Cl}_{2} \mathrm{O}_{3}{ }^{2-}\right]$ and, as a consequence, the initial rate of reaction also does not increase. It does not mean that the $\mathrm{Cl}_{2} \mathrm{O}_{3}{ }^{2-}$ species is stable or can be isolated. It is only an intermediate that is in equilibrium with chlorate and chloride and will react in the next step of the mechanism.

$\mathrm{ClO}_{3}^{-}+\mathrm{Cl}^{-} \rightleftharpoons \mathrm{Cl}_{2} \mathrm{O}_{3}{ }^{2-}$

One important achievement of our work is the $\mathrm{H}^{+}$ third-order behavior at low $\left[\mathrm{Cl}^{-}\right]_{0}$. This result also disagrees with all other results reported before and it is again attributed to the fact that the results in the literature were obtained without ionic strength control, probably because the industrial application of this reaction does not require ionic strength control. Moreover, this order is much more reasonable then an eleventh or thirteenth-order for $\mathrm{H}^{+}$, making unnecessary to suppose effects related with water activity or to use acidity functions to reduce the $\mathrm{H}^{+}$order to lower values.

Another contribution of our work is the observation of a small induction period. This effect has not been reported before, probably because it is necessary to use a stoppedflow equipment to observe it.

\section{Mechanism}

Several authors have proposed mechanisms for this reaction. An important clue was obtained from experiments using ${ }^{38} \mathrm{Cl}$ as tracer: the chlorine atom in $\mathrm{ClO}_{2} \cdot$ comes from chlorate species. ${ }^{23}$ In the same work, Taube and Dodgen $^{23}$ established that reaction must go trough an unsymmetrical intermediate that can be $\mathrm{Cl}-\mathrm{ClO}_{2}$ or $\mathrm{ClOClO}$. Despite the fact that reaction 3 was considered very slow by Taube and Dodgen, ${ }^{23}$ Rapson $^{4,27}$ and also Lenzi and Rapson ${ }^{24}$ proposed proposed the sequence of reactions given by equations 2 to 4 . These reactions account for the $1: 2$ ratio $\mathrm{Cl}_{2}: \mathrm{ClO}_{2} \bullet$. Considering that some $\mathrm{HClO}_{2}$ may react with chloride instead of chlorate, a higher chlorine formation can be explained (equation 2 followed by equations 8 and 4 ).

$\mathrm{HClO}_{2}+\mathrm{Cl}^{-}+\mathrm{H}^{+} \rightarrow 2 \mathrm{HOCl}$

Considering equation 2 as the rate determining step, it can be expected a fourth-order reaction with first-order for chlorate and chloride and second-order for $\mathrm{H}^{+}$, in disagreement with the third-order for $\mathrm{H}^{+}$determined by us. By other hand, if equation 2 is considered as a fast equilibrium followed by equation 3 , a third-order for $\mathrm{H}^{+}$ is obtained, in agreement with our results, but a secondorder for chlorate, in disagreement with the rate law given by equation 6 . This suggests that the mechanism given by equations 2 to 4 cannot be used to explain our results.

The mechanism proposed by Taube and Dodgen, ${ }^{23}$ described by equations 9 and 10, in which the two terminal chlorine atoms of $\mathrm{Cl}_{2} \mathrm{O}_{2}$ meet each other to form chlorine, can not explain the third order for $\mathrm{H}^{+}$neither the saturation profile for $\left[\mathrm{Cl}^{-}\right]_{0}$ but explain the $1: 2$ ratio $\mathrm{Cl}_{2}: \mathrm{ClO}_{2} \bullet$.

$$
\begin{aligned}
& \mathrm{ClO}_{3}^{-}+\mathrm{Cl}^{-}+2 \mathrm{H}^{+} \rightleftharpoons \mathrm{Cl}-\mathrm{ClO}_{2}+\mathrm{H}_{2} \mathrm{O} \\
& 2 \mathrm{Cl}-\mathrm{ClO}_{2} \rightarrow \mathrm{Cl}_{2}+2 \mathrm{ClO}_{2}
\end{aligned}
$$

Then, to explain the orders in the rate law (equation 6), the saturation profile for $\left[\mathrm{Cl}^{-}\right]_{0}$ and the induction period, it is proposed a mechanism that is an expansion of the Taube and Dodgen ${ }^{23}$ mechanism. In our proposal, equation 9 is split in three elementary steps and additional aqueous chlorine chemistry reactions are included (chlorine hydrolysis and formation of $\mathrm{Cl}_{3}{ }^{-}$ion), as shown by equations 11 to 16 . The use of the intermediate $\mathrm{ClOClO}$ instead of $\mathrm{Cl}-\mathrm{ClO}_{2}$ is based on the preferred form for $\mathrm{XOClO}$ species, as implied from kinetic studies of $\mathrm{HOCl}$ reactions. ${ }^{28}$

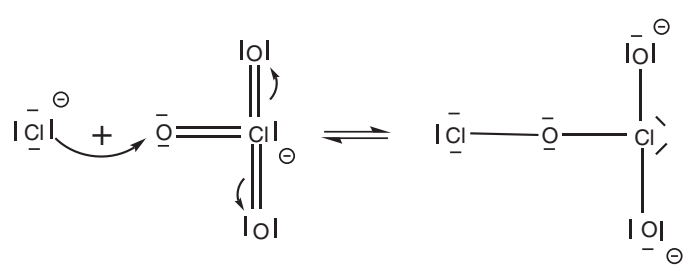




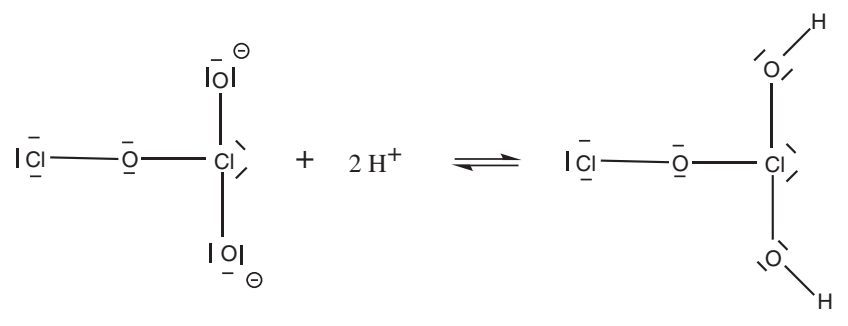

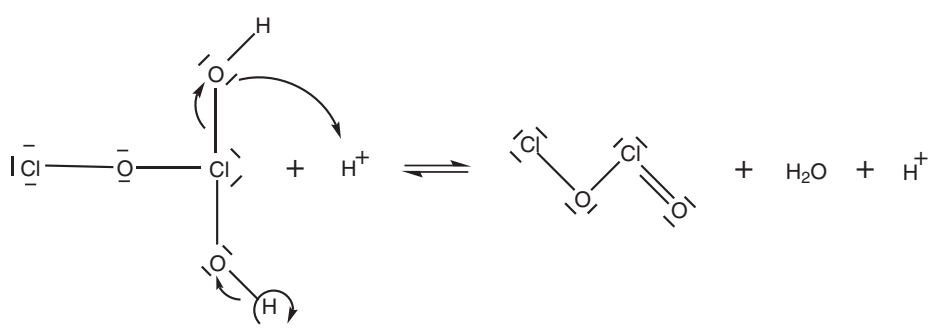

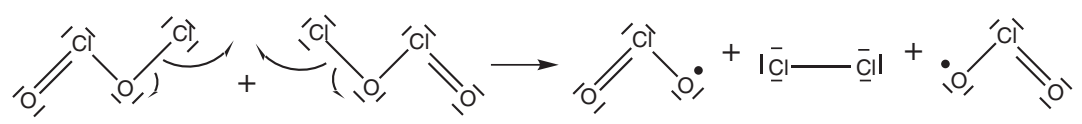

$\mathrm{Cl}_{2}+\mathrm{H}_{2} \mathrm{O} \rightleftharpoons \mathrm{HOCl}+\mathrm{Cl}^{-}+\mathrm{H}^{+}$

$\mathrm{Cl}_{2}+\mathrm{Cl}^{-} \rightleftharpoons \mathrm{Cl}_{3}^{-}$

Numerical integration of this mechanism was done based on the following rate equations (equations 17 to 22) and differential equations (equations 23 to 31 ) for each chemical species. Because $\left[\mathrm{H}^{+}\right]$was much higher than other concentrations, it was considered as a constant:

$\mathrm{V}_{11}=k_{11}\left[\mathrm{ClO}_{3}^{-}\right]\left[\mathrm{Cl}^{-}\right]-k_{-11}\left[\mathrm{Cl}_{2} \mathrm{O}_{3}{ }^{2-}\right]$

$\mathrm{V}_{12}=k_{12}\left[\mathrm{Cl}_{2} \mathrm{O}_{3}{ }^{2-}\right]\left[\mathrm{H}^{+}\right]^{2}-k_{-12}\left[\mathrm{Cl}_{2} \mathrm{O}(\mathrm{OH})_{2}\right]$

$\mathrm{V}_{13}=k_{13}\left[\mathrm{Cl}_{2} \mathrm{O}(\mathrm{OH})_{2}\right]\left[\mathrm{H}^{+}\right]-k_{-13}\left[\mathrm{Cl}_{2} \mathrm{O}_{2}\right]\left[\mathrm{H}^{+}\right]$

$\mathrm{V}_{14}=k_{14}\left[\mathrm{Cl}_{2} \mathrm{O}_{2}\right]^{2}$

$\mathrm{V}_{15}=k_{15}\left[\mathrm{Cl}_{2}\right]-k_{-15}[\mathrm{HOCl}]\left[\mathrm{Cl}^{-}\right]\left[\mathrm{H}^{+}\right]$

$\mathrm{V}_{16}=k_{16}\left[\mathrm{Cl}_{2}\right]\left[\mathrm{Cl}^{-}\right]-k_{-16}\left[\mathrm{Cl}_{3}^{-}\right]$

$\mathrm{d}\left[\mathrm{ClO}_{3}^{-}\right] / \mathrm{dt}=-\mathrm{V}_{11}$

$\mathrm{d}\left[\mathrm{Cl}^{-}\right] / \mathrm{dt}=-\mathrm{V}_{11}+\mathrm{V}_{15}-\mathrm{V}_{16}$

$\mathrm{d}\left[\mathrm{Cl}_{2} \mathrm{O}_{3}{ }^{2-}\right] / \mathrm{dt}=\mathrm{V}_{11}-\mathrm{V}_{12}$

$\mathrm{d}\left[\mathrm{Cl}_{2} \mathrm{O}(\mathrm{OH})_{2}\right] / \mathrm{dt}=\mathrm{V}_{12}-\mathrm{V}_{13}$

$\mathrm{d}\left[\mathrm{Cl}_{2} \mathrm{O}_{2}\right] / \mathrm{dt}=\mathrm{V}_{13}-2 \mathrm{~V}_{14}$

$\mathrm{d}\left[\mathrm{Cl}_{2}\right] / \mathrm{dt}=\mathrm{V}_{14}-\mathrm{V}_{15}-\mathrm{V}_{16}$

$\mathrm{d}\left[\mathrm{Cl}_{3}^{-}\right] / \mathrm{dt}=\mathrm{V}_{16}$

The numerical integration results show that the proposed mechanism is able to model the chlorate-chloride reaction at different wavelengths ( 358 and $400 \mathrm{~nm}$ ), different $\left[\mathrm{H}^{+}\right]$and at low and high $\left[\mathrm{Cl}^{-}\right]$, as shown in Figure 5, including the small induction period. The rate constants employed are presented in Table 9. To calculate the absorbance at 358 or $400 \mathrm{~nm}$, the following molar absorbance coefficients were employed: (i) at $358 \mathrm{~nm}: \varepsilon\left(\mathrm{ClO}_{2}{ }^{\bullet}\right)=1250 \mathrm{~mol}^{-1} \mathrm{~L} \mathrm{~cm}^{-1}$, $\varepsilon\left(\mathrm{Cl}_{2}\right)=33.5 \mathrm{~mol}^{-1} \mathrm{~L} \mathrm{~cm}^{-1}$ and $\varepsilon\left(\mathrm{Cl}_{3}^{-}\right)=81 \mathrm{~mol}^{-1} \mathrm{~L} \mathrm{~cm}^{-1}$ and

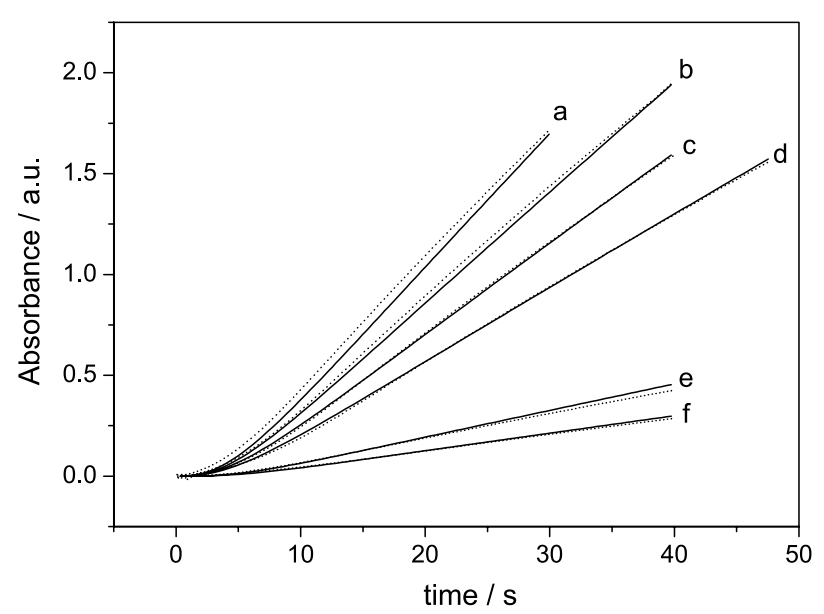

Figure 5. Comparison between experimental and modeling curves; experimental (dot), model (continuous line): $\left[\mathrm{ClO}_{3}^{-}\right]_{0}=0.2 \mathrm{~mol} \mathrm{~L}^{-1}$ (a-f), $\left[\mathrm{Cl}^{-}\right]_{0}=3.8 \mathrm{~mol} \mathrm{~L}^{-1}(\mathrm{a}-\mathrm{d}),\left[\mathrm{Cl}^{-}\right]_{0}=0.5 \mathrm{~mol} \mathrm{~L}^{-1}(\mathrm{e}, \mathrm{f}),\left[\mathrm{H}^{+}\right]_{0}=3.8 \mathrm{~mol} \mathrm{~L}^{-1}$ (a), $\left[\mathrm{H}^{+}\right]_{0}=3.6 \mathrm{~mol} \mathrm{~L}^{-1}(\mathrm{~b}),\left[\mathrm{H}^{+}\right]_{0}=3.4 \mathrm{~mol} \mathrm{~L}^{-1}(\mathrm{c}),\left[\mathrm{H}^{+}\right]_{0}=3.2 \mathrm{~mol} \mathrm{~L}^{-1}$ (d), $\left[\mathrm{H}^{+}\right]_{0}=3.7 \mathrm{~mol} \mathrm{~L}^{-1}(\mathrm{e})$, and $\left[\mathrm{H}^{+}\right]_{0}=3.3 \mathrm{~mol} \mathrm{~L}^{-1}(\mathrm{f}), \lambda$ at $358(\mathrm{a}-\mathrm{d})$ and $400 \mathrm{~nm}(\mathrm{e}, \mathrm{f})$.

Table 9. Rate constants for equations 11 to 16 used to model the kinetic curves in Figure 5

\begin{tabular}{lcc}
\hline Reaction & $k$ & $k$ (reverse) \\
\hline 11 & $2 \mathrm{~mol}^{-1} \mathrm{~L} \mathrm{~s}^{-1}$ & $0.4 \mathrm{~s}^{-1}$ \\
12 & $2 \times 10^{-4} \mathrm{~mol}^{-2} \mathrm{~L}^{2} \mathrm{~s}^{-1}$ & $0.22 \mathrm{~s}^{-1}$ \\
13 & $8 \times 10^{2} \mathrm{~mol}^{-1} \mathrm{~L} \mathrm{~s}^{-1}$ & $8 \times 10^{3} \mathrm{~mol}^{-1} \mathrm{~L} \mathrm{~s}^{-1}$ \\
14 & $9 \times 10^{2} \mathrm{~mol}^{-1} \mathrm{~L} \mathrm{~s}^{-1}$ & \\
15 & $22 \mathrm{~s}^{-1}$ & $2.2 \times 10^{4} \mathrm{~mol}^{-2} \mathrm{~L}^{2} \mathrm{~s}^{-1}$ \\
16 & $1.8 \times 10^{9} \mathrm{~mol}^{-1} \mathrm{~L} \mathrm{~s}^{-1}$ & $1 \times 10^{10} \mathrm{~s}^{-1}$ \\
\hline
\end{tabular}


(ii) at $400 \mathrm{~nm} \varepsilon\left(\mathrm{ClO}_{2} \cdot\right)=607 \mathrm{~mol}^{-1} \mathrm{~L} \mathrm{~cm}^{-1}$, $\varepsilon\left(\mathrm{Cl}_{2}\right)=4 \mathrm{~mol}^{-1} \mathrm{~L} \mathrm{~cm}^{-1}$ and $\varepsilon\left(\mathrm{Cl}_{3}^{-}\right)=8 \mathrm{~mol}^{-1} \mathrm{~L} \mathrm{~cm}^{-1}$.

The rate constants for reaction 15 were taken from the modeling work for the $\mathrm{ClO}_{2}-\mathrm{I}^{-}$reaction ${ }^{11}$ that is based on experimental values. ${ }^{29}$ The rate constants for reaction 16 were based on the average experimental value for the equilibrium constant. ${ }^{25}$ The rate constant values for reactions 11 to 14 were the best values found by us after several steps of carefully adjustment to make the model fit the experimental absorbance versus time curves. They are not completely independent from each other and other sets of these rate constants may produce a similar fit.

As this mechanism contains three equilibrium reactions before the determining step, three intermediates may accumulate. This can explain the feature at ca. $270 \mathrm{~nm}$ in Figure $1 \mathrm{~b}$ that can be due to any of the species $\mathrm{Cl}_{2} \mathrm{O}_{3}{ }^{2-}$, $\mathrm{Cl}_{2} \mathrm{O}(\mathrm{OH})_{2}$ or $\mathrm{ClOClO}$ (most probable the $\mathrm{Cl}_{2} \mathrm{O}_{3}{ }^{2-}$ ) because this feature appears in excess of chloride.

\section{Conclusions}

In a medium with constant ionic strength and low chloride concentration, the chlorate-chloride reaction presents a third order for $\mathrm{H}^{+}$which is a value much more reasonable than the reaction order values higher than ten, found by other authors. Chlorate and chloride show a first-order behavior and the reaction presents an induction period that can be seen only using stopped-flow technique. At high chloride initial concentrations, the order for chloride approaches zero.

However, these order values cannot be strictly taken because they are based on initial rate values measured after the induction period. In these cases, it is more reliable to propose a mechanism and submit it to numerical integration to check if it is able to model the experimental kinetic curves.

The proposed mechanism (reactions 11 to 16) includes a fast equilibrium in which chlorate and chloride form the intermediate $\mathrm{Cl}_{2} \mathrm{O}_{3}{ }^{2-}$. This one, after protonation and water loss, produces $\mathrm{ClOClO}$, which reacts with itself to produce $\mathrm{Cl}_{2}$ and $\mathrm{ClO}_{2} \cdot$ in a ratio $1: 2$, in agreement with experimental observations reported in the literature. The mechanism was able to model the experimental curves obtained at 358 and $400 \mathrm{~nm}$, at several $\left[\mathrm{H}^{+}\right]_{0}$ and specially at low and high $\left[\mathrm{Cl}^{-}\right]_{0}$, i.e., in the two range of chloride concentrations in which the chloride ion presents first- and zero-order dependence, respectively.

\section{Acknowledgments}

This work was supported by Conselho Nacional de Desenvolvimento Científico e Tecnológico (CNPq),
Fundação de Amparo à Pesquisa do Estado do Rio de Janeiro (FAPERJ) and Financiadora de Estudos e Projetos (FINEP).

\section{References}

1. Büchel, K. H.; Moretto, H.-H.; Woditsch, P.; Industrial Inorganic Chemistry, $2^{\text {nd }}$ ed.; Wiley-VCH: Weiheim, 2000, p. $166-175$.

2. Rapson, W. H.; Tappi J. 1954, 37, 129.

3. Burke, M.; Tenney, J.; Indu, B.; Fazul Hoq, M.; Carr, S.; Ernest, W. R.; Ind. Eng. Chem. Res. 1993, 32, 1449.

4. Rapson, W. H.; Tappi J. 1958, 41, 181.

5. Sand, J.; Z. Phys. Chem. 1905, 50, 465.

6. Bray, W.; Z. Phys. Chem. 1906, 54, 569.

7. Luther, R.; MacDougall, F. H.; Z. Phys. Chem. 1906, 55, 477.

8. Luther, R.; MacDougall, F. H.; Z. Phys. Chem. 1908, 62, 199.

9. Hirade, J.; Bull. Chem. Soc. Jpn. 1935, 10, 97.

10. Gordon, G.; Kieffer, R. G.; Rosenblatt, D. H.; Prog. Inorg. Chem. 1972, 15, 201.

11. Lengyel, I.; Li, J.; Kustin, K.; Epstein, I. R.; J. Am. Chem. Soc. 1996, 118, 3708.

12. Oliveira, A. P.; Faria, R. B.; J. Am. Chem. Soc. 2005, 127, 18022.

13. Galadja, M.; Lent, G.; Fábian, I.; J. Am. Chem. Soc. 2007, 129, 7738.

14. Hong, C. C.; Lenzi, F.; Rapson, W. H.; Can. J. Chem. Eng. 1967, 45, 349.

15. Lenzi, F.; Rapson, W. H.; Can. J. Chem. 1968, 46, 979.

16. Crisci, P.; Lenzi, F.; Can. J. Chem. 1971, 49, 2552.

17. Deshwal, B. R.; Lee, H.-K.; J. Hazard Mater. 2004, 108, 173.

18. Horváth, A. K.; Nagypal, I.; Peintler, G.; Epstein, I. R.; Kustin, K.; J. Phys. Chem. A 2003, 107, 6966.

19. Kormányos, B.; Nagypal, I.; Peintler, G.; Horváth, A. K.; Inorg. Chem. 2008, 47, 7914.

20. Kieffer, R. G.; Gordon, G.; Inorg. Chem. 1968, 7, 235.

21. Côrtes, C. E. S.; Faria, R. B,; Inorg. Chem. 2004, 43, 1395.

22. Kaps, P.; Rentrop, P.; Numer. Math. 1979, 33, 55.

23. Taube, H.; Dodgen, H.; J. Am. Chem. Soc. 1949, 71, 3330.

24. Lenzi, F.; Rapson, W. H.; Pulp Paper Mag. Can. 1962, 63, T442.

25. Wang, T. X.; Kelley, M. D.; Cooper, J. N.; Beckwith, R. C.; Margerum, D. W.; Inorg. Chem. 1994, 33, 5872.

26. Pitzer, K. S.; Roy, R. N.; Silvester, L.F.; J. Am. Chem. Soc. 1977, 99, 4930.

27. Rapson, W. H.; Tappi J. 1956, 39, 554.

28. Nicoson, J. S.; Perrone, T. F.; Hartz, K. E. H.; Wang, L.; Margerum, D. W.; Inorg. Chem. 2003, 42, 5818.

29. Wang, T. X.; Margerum, D. W.; Inorg. Chem. 1994, 33, 1050. 